の圧迫，(6)20分以内の検查所要時間，(7)肚門耪併用の敩 守，亿注意する必要がある。

\section{DSA における拡大撮影の問題点について}

国立循環器病センター放射線診断部

○東儀英明・栗井一夫

由中 勲・若松孝司

〔目的〕DSA は経静脈性および動脈性より，血管造 影を行いSubtration 像を得られる新しい検査法である. DSA に打ける撮影技術の方法として，今回，AOT， Puck 等の搪大撮影と同様に Grid 12-1, 6-1, grid (-) の contrast について比較検討を行った。

〔結果】(1)拡大率を大きし，Grid を除去した場合は， contrast は高くなる. (2) Grid 除去と grid 12:1では, grid 除去の方方管電圧 $15 \mathrm{kV}$ 少なくできる.（但し 2 倍 拡大) (3)I·I・面加ら被写体を $40 \mathrm{~cm}$ 離す事により（FID $100 \mathrm{~cm}$ であれば約 1.8 倍）グレーテル効果で散乱線の影 響を低減できる。

\section{Temporal band pass filter による Digital Subt- raction Angio Tomography $の$ 基礎研究}

国立循環器病センター放射線診療部 ○粟井一夫・東儀英明・若松孝司

DSA は造影剤を静注するととにより動脈像を得られ るのが大きな利点の1つである。しかし，静注 DSA で は目的とする血管以外の I.I. 視野内すべての動脈が造影 され，目的血管之重複し䧐断能が低下する欠点がある。 われわれは DSA に断層を応用することにより血管の重 複などのアーチファクトを除去するのを目的として基礎 実験を行った。

実験結果としてファントムでは一応の成果はみられた が市販の DSA 装置には断層の機構がなく，また bandpass filter 屯理想的な filter を得るには高伍であるなど の問題点がある.

\section{座長集約}

このセクションは，造影撮影に関する 4 演題が，2つ の施設より発表された．第11席は，ルチン贯X線撮影に おける問題点，第12席は注腸ルチン検查に関する問題点 について，それぞれ，撮影体位等について発表した。乙 れらに対して，星ケ丘厚生年金病院の長畑より若干の質 問があった．第13席，14帛は DR に関する演題であり， 13 席は，DSA における拡大撮影の問題点について， DSA による挂大撮影と, 従来の搪大撮影との比較, 特に contrastについて検討した結果を発表した。14席は， Tempral band pass filter 用いて, DSA $の$ tomography を試みた結果を発表した。乙れらに対して，阪大の
花山より，造影剤濃度の表示を\%で表示しているがヨー ドの含有量で表示する方が良いのではないか，また，14 席に詨してこの方法での限界点等の質問が出た.

\section{超音波}

座長 笠置良之（水間医院）

\section{5. 膵超音波における膵陰影不明症例の検討}

大橋病院放射線診断部 (京都伏見)

○沢田善之・浅田栄一・鹿島健二 馬場貴美子・西内利枝 $\cdot$ 大橋 広 癌研究会附属病院放射線診断部飯塚 修 萃超音波検査で常に膵全体を描出することは，難しく， 一部或は全体不明な場合が多しことから膵陰影描出能に ついて検討した．当院で行った膵超音波検查は1982年11 月より 9 力月間で579件でそのうち, 膵陰影, 全体描出143 例，一部不明111例，全体不明197例であった。これらの うち一部执よび全体不明群308例（68\%）について CT, ERCPで精查を行ったところ，CTで16例（5\%）， ERCP は 9 例 (3\%) 亿病変力諗められ最終的に19例(6.2 \%) 上なり膵超音波検査のみで膵病変を検索する場合， 膵陰影描出能が重要な課題となる.したがってその描出 方法の工夫がいかに大切であるかがわかった。

\section{6. ルチン肝超音波検查の一考察}

大橋病院放射線診断部（京都伏見）

○西内利枝・浅田栄一・沢田善之

鹿島健二・馬場貴美子・大橋 広

癌研究会附属病院放射線診断部 飯塚 修

肝エコーは，多方向からのスキャンが可能であるため に，エコー像上の描出区域がはっきりしない。そてで肝 病変のエコー像と CT 像とを比較し, クノ一の肝区域分 類を用いてエコー像上の区域境界線を決定した。対象は， 1983 年 1 月から 8 月までに肝エコー検查を行った 985 件 中肝疾患が存在した19例31病変で, このうち描出不可能 であったものは 6 病変である，今回の検討により，肝エ コ一検查で比較的描出されやすいのは, 右前後下区域, 左 内側区域, 左外側下区域であり, 右前後上区域, 左外側上 区域の一部は，描出不可能な区域であった。また, $10 \mathrm{~mm}$ 以下の小病変や肝表面の病変，あるいは，正常肝之音響 インピーダンスの差が少ない病変は描出不可能であった.

\section{座長集約}

15席沢田君の発表は，膵超音波検査においての膵描出 能と不描出者の CT・ERCP 精査を比較したもので膵超 音波検査時に検者全員が持つ悩みである。体位変換や無 気水の飲用等皆工夫をしていることであるが……16席 西内君の発表は，旰ルチン検査時における聅病の位置つ 